\title{
Antibiogram and Coagulase Diversity in Staphylococcal Enterotoxin- Producing Staphylococcus aureus from Bovine Mastitis
}

\author{
J. S. Moon, ${ }^{\star}$ A. R. Lee, $†$ H. M. Kang, ${ }^{*}$ E. S. Lee, ${ }^{*}$ Y. S. Joo, ${ }^{*}$ Y. H. Park, $\ddagger$ M. N. Kim, $†$ and H. C. Koo ${ }^{1}$ \\ *Department of Bacteriology, National Veterinary Research and Quarantine Service, Anyang, Gyeonggi-do, Korea \\ †Department of Biology, Sangmyung University, Seoul \\ ¥KRF Zoonotic Disease Priority Research Institute, Department of Microbiology, College of Veterinary Medicine and the BK21 program \\ for Veterinary Science, Seoul National University, Seoul, Republic of Korea
}

\begin{abstract}
We investigated antibiogram and coagulase gene diversity in staphylococcal enterotoxin (StE)-producing Staphylococcus aureus isolated from raw milk samples of cows infected with mastitis from 140 dairy farms in Korea between 1997 and 2004. Of the 696 Staph. aureus isolates collected in this study, 164 isolates $(23.6 \%)$ produced one or more staphylococcal enterotoxins (A to D), and 19 isolates $(2.7 \%)$ were methicillin-resistant. The percentage of StE-producing Staph. aureus (SES) isolates resistant to methicillin, kanamycin, neomycin, amikacin, and tetracycline was greater than that of non-SES. Ten coagulase genotype patterns were observed, including 4 main types comprising I (25.4\%), II (13.9\%), VII (13.2\%), and VIII (17.8\%). More than 4 Staph. aureus types were isolated from each of 82 dairy farms in different geographic locations, and only 1 coagulase genotype pattern was observed in 39 of the herds (47.6\%). There was no significant correlation between coagulase genotypes harbored by Staph. aureus and their specific StE type. The percentage of isolates producing major StE types (A, B, AC, and ABCD) and being resistant to cephalothin and methicillin was greater among the Staph. aureus isolates with the 4 predominant coagulase genotypes (I, II, VII, and VIII) than among the isolates harboring the 6 rare coagulase types (III, IV, V, VI, IX, and X). Based on coagulase gene polymorphisms, our data indicate that a broad distribution of identical or closely related enterotoxin-producing Staph. aureus strains seem to contribute to bovine mastitis in the Republic of Korea.
\end{abstract}

Key words: bovine mastitis, Staphylococcus aureus, enterotoxin, coagulase polymorphism

\section{INTRODUCTION}

Bovine mastitis is a major disease that affects the dairy industry, and Staphylococcus aureus is one of the

Received August 5, 2006.

Accepted November 6, 2006.

${ }^{1}$ Corresponding author: koohj@snu.ac.kr most frequently isolated pathogens from both subclinical and chronic infections (Watts, 1988; Bramley, 1992). Some Staph. aureus isolates from bovine milk carry different staphylococcal enterotoxins (StE) or toxic shock syndrome toxin-1 (Kenny et al., 1993; Matsunaga et al., 1993). These toxins are responsible for food poisoning outbreaks and toxigenic syndrome in humans respectively (Llewelyn and Cohen, 2002); they may also contribute to the persistence of Staph. aureus in bovine mammary glands and increased udder pathogenicity (Ferens et al., 1998).

Several reports (Larsen et al., 2000; Stephan et al., 2001; da Silva et al., 2005) have noted that the production of StE in Staph. aureus isolated from bovine mastitis may be determined by environmental and management factors in each geographical area. This genetic variability in StE production contributed to the emergence of distinct epidemiological profiles that were dependent on predominant strains within a herd. It indicates the necessity to identify such strains or subtypes before applying specific measures of mastitis control (Larsen et al., 2000; Stephan et al., 2001; da Silva et al., 2005). In addition, the staphylococcal enterotoxin C (SEC)-producing strains have been isolated frequently from bovine mastitis in northeast Switzerland (Stephan et al., 2001), Brazil (da Silva et al., 2005), and Japan (Katsuda et al., 2005). Recently, the occurrence of new types of StE (SEG to SER and SEU) has been reported, but the relationship between these new $\mathrm{StE}$ and bovine mastitis has not been established (Katsuda et al., 2005).

Many molecular epidemiological studies have already been conducted on enterotoxigenic Staph. aureus isolated from bovine milk, food, and humans (Tsen and Chen, 1992; Cremonesi et al., 2005; Boerema et al., 2006). Polymerase chain reaction and PCR-RFLP analysis of the $3^{\prime}$ end of the gene encoding staphylococcal coagulase (coa) have been proposed as methods for typing Staph. aureus isolates for epidemiological study. It was previously described that varying numbers ( 3 to 9 ) of 81-bp tandem repeats in the coa gene determined sequence analysis (Lange et al., 1999; Scherrer et al., 
2004). Amplified DNA fragments of different sizes can be further discriminated by digestion with $A l u \mathrm{I}$ (Goh et al., 1992). This PCR-based genotyping method has provided detailed epidemiological information about Staph. aureus (Schwarzkopf and Karch, 1994; Hookey et al., 1998).

In the last few years, the results of epidemiologic research based on the polymorphism of the coa gene in different countries indicate that a few Staph. aureus subtypes are responsible for most cases of bovine mastitis, and that these clones have a broad geographic distribution (Fitzgerald et al., 1997; Annemüller et al., 1999; Lange et al., 1999; da Silva and da Silva, 2006). Despite this detailed genetic characterization of StE-producing Staph. aureus (SES) in other countries, little is currently known of SES isolates from bovine milk in the Republic of Korea. An understanding of this epidemiological relationship is also necessary for the design of more effective mastitis control programs against enterotoxigenic Staph. aureus. Based on the previous experience in epidemiological investigation by PCR-RFLP analysis of the coa gene of Staph. aureus isolated from bovine mastitis in our study (Moon et al., 2003, 2007; Lim et al., 2004), we characterized subtypes and antibiograms of SES isolates derived from bovine mastitis milk collected from different provinces of the Republic of Korea by PCR-based subtying of the coa gene.

\section{MATERIALS AND METHODS}

\section{Milk Sampling}

One hundred forty herds located in the Republic of Korea (Table 1) with mastitis problems (bulk milk SCC greater than 200,000 cell $\mathrm{s} / \mathrm{mL}$ ) were selected for possible further study from August 1997 to December 2004. The SCC was measured by using a Milkoscan 4000 (Foss Electric Co., Hillerød, Denmark). Milk samples were collected using aseptic technique from individual quarters of the cows that were suspected to have subclinical mastitis as detected by high SCC and clinical observation, and the samples were cultured according to standard protocols suggested by the National Mastitis Council (Harmon et al., 1990).

\section{Isolation and Identification of Staph. aureus and Enterotoxin Production}

Staphylococcus aureus was isolated from milk samples in dairy herds according to the protocols of the National Mastitis Council (Harmon et al., 1990). An aliquot of $10 \mu \mathrm{L}$ from each sample was spread over blood agar plates (Bacto-Agar, Difco, Detroit, MI) containing $5 \%$ washed sheep erythrocytes and incubated at $37^{\circ} \mathrm{C}$ for $24 \mathrm{~h}$. Colonies suspected of being staphylococci

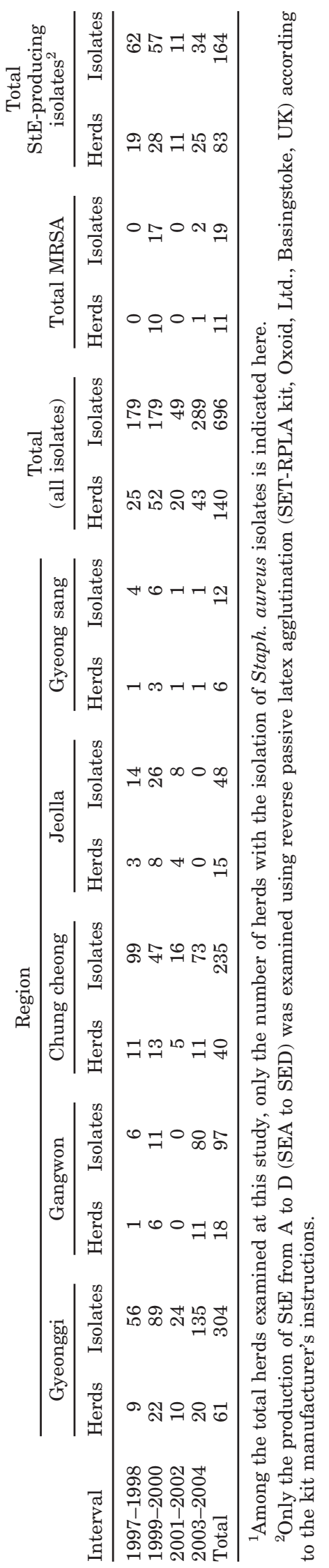

Journal of Dairy Science Vol. 90 No. 4, 2007 
were subcultured on blood agar plates, and isolation and identification of Staph. aureus was performed by the method of Roberson et al. (1992) as follows: Gram staining, coagulase test, Baird-Parker medium culture test, DNase test, Voges-Proskauer test, mannitol fermentation test, and Vitek GPI card (bioMerieux, Lyon, France). Isolates of Staph. aureus were kept refrigerated $\left(-70^{\circ} \mathrm{C}\right)$ for this study. The production of $\mathrm{StE}$ was examined using a staphylococcal enterotoxin A, B, C, $\mathrm{D}$ detection by reverse passive latex agglutination) according to the instructions of the kit manufacturer (Oxoid Ltd., Basingstoke, UK).

\section{Antibiotic Susceptibility Test}

The MIC test for methicillin (oxacillin) resistance and disk diffusion test on Müller-Hinton agar (Difco, Sparks, MD) for other antibiotics were performed and interpreted as recommended by the Clinical and Laboratory Standards Institute (CLSI, 2002; formerly the National Committee for Clinical Laboratory Standards). Commercially available (BBL, Sparks, MD) disks of antimicrobial drugs that are used frequently for the treatment of mastitis in lactating and dry cows in Korean dairy herds were tested in this study. The plates were incubated at $30^{\circ} \mathrm{C}$ for oxacillin $(1 \mu \mathrm{g} / \mathrm{disk})$ and $37^{\circ} \mathrm{C}$ for other antibiotics, including penicillin $\mathrm{G}$ (10 units/disk), ampicillin (10 $\mu \mathrm{g} /$ disk), cephalothin (30 $\mu \mathrm{g} /$ disk $)$, amikacin (30 $\mu \mathrm{g} /$ disk $)$, gentamicin (10 $\mu \mathrm{g} /$ disk), neomycin (30 $\mu \mathrm{g} /$ disk), kanamycin (30 $\mu \mathrm{g} / \mathrm{disk})$, and tetracycline $(30 \mu \mathrm{g} / \mathrm{disk})$. Methicillin resistance of staphylococci was screened by disk diffusion test with an oxacillin disk on Muller-Hinton agar and confirmed by MIC test with oxacillin. Phenotypic methicillin resistance was defined with an oxacillin MIC $\geq 4 \mu \mathrm{g} / \mathrm{mL}$. Staphylococcus aureus ATCC 25923 was purchased from the American Type Culture Collection (Manassas, VA) and used as a quality control standard. Zones of growth inhibition were evaluated according to CLSI (2002).

\section{Coagulase Gene Typing}

DNA Extraction for Amplification. Whole cellular DNA was isolated as described by Hookey et al. (1998) with some modifications. Cells grown in $1.5 \mathrm{~mL}$ of brain heart infusion broth (BHI, Difco) at $37^{\circ} \mathrm{C}$ for $24 \mathrm{~h}$ were harvested, centrifuged at $16,000 \times g$ for $3 \mathrm{~min}$, washed twice with $0.7 \mathrm{~mL}$ of Tris-EDTA (TE) buffer $(10 \mathrm{mM}$ Tris HCl, $1 \mathrm{~m} M$ EDTA, $\mathrm{pH}$ 8.0), and resuspended in TE buffer. To the cells were added $30 \mu \mathrm{L}$ of $20 \%$ SDS (Sigma, St. Louis, MO), $5 \mu \mathrm{L}$ of proteinase K $(20 \mathrm{mg} /$ $\mathrm{mL}$, Promega Corp., Madison, WI), $50 \mu \mathrm{L}$ of lysozyme (200 $\mu \mathrm{g} / \mathrm{mL}$, Sigma), and the solutions were then mixed and incubated at $37^{\circ} \mathrm{C}$ for $90 \mathrm{~min}$. To this mixture was added $100 \mu \mathrm{L}$ of $\mathrm{CTAB} / \mathrm{NaCl}[10 \%$ cetyltrimethylammonium bromide (wt/vol), $0.7 \% \mathrm{NaCl}$; Sigma]. The mixture was then incubated at $65^{\circ} \mathrm{C}$ for $20 \mathrm{~min}$ and centrifuged at $12,000 \times g$ for $15 \mathrm{~min}\left(4^{\circ} \mathrm{C}\right)$. The lysate was extracted with equal volumes of phenol:chloroform:isoamylalcohol (25:24:1, Sigma) and centrifuged at $12,000 \times g$ for $15 \mathrm{~min}\left(4^{\circ} \mathrm{C}\right)$. The supernatant in aqueous phase was added to 1 volume of chloroform:isoamylalcohol (24:1, Sigma) and centrifuged at $12,000 \times g$ for $15 \min \left(4^{\circ} \mathrm{C}\right)$. The DNA was precipitated from the aqueous phase with 2 to 3 volumes of isoamylalcohol at $-70^{\circ} \mathrm{C}$ overnight. After centrifugation, the pellet was washed with $70 \%$ ethanol, dried with a vacuum drier, and resuspended with $30 \mu \mathrm{L}$ of TE buffer (Sigma). The DNA concentration was determined by UV spectrophotometry (Bio-Rad Laboratories Inc., Hercules, CA) at $260 \mathrm{~nm}$, and the extract was stored at $4^{\circ} \mathrm{C}$. Approximately 50 to $100 \mathrm{ng}$ of DNA was taken for PCR amplification.

Analysis of Coagulase Gene by PCR-RFLP of Staph. aureus. Primers for analysis of the coa gene of Staph. aureus by PCR-RFLP were constructed as described by Kaida et al. (1989). The forward primer, Coa-1 (5'-ATAGAAATGCTGGTACAGG-3'; MRSA 213; Accession No. X16457; 1,513 to 1,531), and the reverse primer, Coa-2 (5'-GCTTCCGATTGTTCGATGC-3'; 2,188 to 2,168 ), were used. The numbers in parentheses refer to the positions on the coa gene sequence. In this study, PCR was performed as described by Hookey et al. (1998) with some modifications. In brief, PCR was performed in a $50-\mu \mathrm{L}$ volume with $10 \times$ PCR buffer (Promega) containing $100 \mathrm{mM}$ Tris- $\mathrm{HCl}(\mathrm{pH} \mathrm{8.3),} 50 \mathrm{mM}$ $\mathrm{KCl}, 6 \mu \mathrm{L}$ of $\mathrm{MgCl}_{2}$ (25 mM, Promega), $400 \mu M$ dNTP mixture (Promega), 2.5 U of Taq polymerase (Promega), and $1 \mu \mathrm{L}$ of each primer $(100 \mathrm{pmol} / \mu \mathrm{L}), 2.5 \mu \mathrm{L}$ of dimethyl sulfoxide, and $100 \mathrm{ng}$ of DNA template. Finally, PCR-grade water (Sigma) was added to a final volume of $50 \mu \mathrm{L}$. Amplification of DNA was performed using the following cycling parameters: predenaturation at $94^{\circ} \mathrm{C}$ for $5 \mathrm{~min}$ for 1 cycle, followed by denaturation at $94^{\circ} \mathrm{C}$ for $20 \mathrm{~s}$, annealing at $58^{\circ} \mathrm{C}$ for $15 \mathrm{~s}$, and extension at $70^{\circ} \mathrm{C}$ for $15 \mathrm{~s}$ for 35 cycles on a thermal cycler (model 2400, Perkin-Elmer Life and Analytical Sciences, Boston, MA). A 7-min extension step at $72^{\circ} \mathrm{C}$ was included at the end of the final cycle. After electrophoresis, the gel was stained with ethidium bromide and visualized by UV light. Each PCR product $(10 \mu \mathrm{L})$ was incubated with 2 units of $A l u \mathrm{I}$ restriction endonucleases (Promega) for $1 \mathrm{~h}$ at $37^{\circ} \mathrm{C}$ according to the manufacturer's protocol. The resulting fragments were electrophoresed on a $2.75 \%$ agarose gel at $110 \mathrm{~V}$ for $1 \mathrm{~h}$, stained with ethidium bromide $(0.5 \mu \mathrm{g} / \mathrm{mL})$, and visualized under UV light. 
Table 2. Distribution of toxin production of staphylococcal enterotoxin (StE)-producing Staphylococcus aureus and PCR-RFLP genotypes of the coagulase gene of Staph. aureus isolated from milk of mastitic dairy cows

\begin{tabular}{|c|c|c|c|c|c|c|c|c|c|c|c|c|}
\hline \multirow{2}{*}{ StE production } & & \multirow{2}{*}{$\begin{array}{c}\text { No. of } \\
\text { isolates }\end{array}$} & \multicolumn{10}{|c|}{ PCR-RFLP types (coagulase genotype) } \\
\hline & & & I & II & III & IV & $\mathrm{V}$ & VI & VII & VIII & IX & $\mathrm{X}$ \\
\hline \multirow[t]{14}{*}{ StE-producing } & $\mathrm{A}$ & 73 & 11 & 5 & 11 & 1 & 2 & 4 & 9 & 23 & 1 & 6 \\
\hline & B & 17 & 2 & 4 & 0 & 1 & 2 & 0 & 7 & 1 & 0 & 0 \\
\hline & C & 8 & 4 & 1 & 0 & 0 & 0 & 1 & 0 & 0 & 2 & 0 \\
\hline & D & 2 & 0 & 1 & 0 & 0 & 0 & 0 & 0 & 1 & 0 & 0 \\
\hline & $\mathrm{AB}$ & 2 & 0 & 0 & 0 & 0 & 0 & 0 & 1 & 1 & 0 & 0 \\
\hline & $\mathrm{AC}$ & 13 & 1 & 8 & 0 & 0 & 0 & 0 & 0 & 3 & 1 & 0 \\
\hline & $\mathrm{AD}$ & 4 & 3 & 1 & 0 & 0 & 0 & 0 & 0 & 0 & 0 & 0 \\
\hline & $\mathrm{BC}$ & 3 & 2 & 0 & 0 & 0 & 0 & 0 & 0 & 0 & 1 & 0 \\
\hline & CD & 1 & 0 & 0 & 0 & 0 & 1 & 0 & 0 & 0 & 0 & 0 \\
\hline & $\mathrm{ABC}$ & 4 & 1 & 0 & 0 & 0 & 0 & 1 & 0 & 2 & 0 & 0 \\
\hline & ACD & 4 & 0 & 0 & 0 & 0 & 0 & 0 & 0 & 2 & 2 & 0 \\
\hline & BCD & 6 & 0 & 3 & 0 & 1 & 0 & 1 & 1 & 0 & 0 & 0 \\
\hline & ABCD & 27 & 4 & 5 & 2 & 1 & 0 & 5 & 3 & 6 & 1 & 0 \\
\hline & Subtotal & 164 & $\begin{array}{l}28 \\
(17)^{2}\end{array}$ & $\begin{array}{c}28 \\
(17)\end{array}$ & $\begin{array}{l}13 \\
(8)\end{array}$ & $\begin{array}{c}4 \\
(2)\end{array}$ & $\begin{array}{c}5 \\
(3)\end{array}$ & $\begin{array}{l}12 \\
(7)\end{array}$ & $\begin{array}{c}21 \\
(13)\end{array}$ & $\begin{array}{c}39 \\
(24)\end{array}$ & $\begin{array}{c}8 \\
(5)\end{array}$ & $\begin{array}{c}6 \\
(4)\end{array}$ \\
\hline \multicolumn{2}{|c|}{ Non-StE-producing } & 532 & $\begin{array}{l}149 \\
(28)^{2}\end{array}$ & $\begin{array}{c}69 \\
(13)\end{array}$ & $\begin{array}{l}12 \\
(2)\end{array}$ & $\begin{array}{l}47 \\
(9)\end{array}$ & $\begin{array}{c}54 \\
(10)\end{array}$ & $\begin{array}{l}13 \\
(2)\end{array}$ & $\begin{array}{c}71 \\
(13)\end{array}$ & $\begin{array}{l}85 \\
(16)\end{array}$ & $\begin{array}{l}29 \\
(5)\end{array}$ & $\begin{array}{c}3 \\
(1)\end{array}$ \\
\hline
\end{tabular}

\footnotetext{
${ }^{1}$ Only production of StE from A to D (SEA to SED) was examined using reverse passive latex agglutination (SET-RPLA kit, Oxoid, Ltd., Basingstoke, UK) according to the kit manufacturer's instructions.

${ }^{2}$ Values in parentheses indicate the percentage of Staph. aureus isolates with each PCR-RFLP type of coagulase gene among StE-producing or nonproducing Staph. aureus isolates.
}

\section{Statistical Analyses}

The Mantel-Haenszel $\chi^{2}$ test and Fisher's exact test were used to examine differences in the observed antibiotic susceptibility percentage between Staph. aureus isolates with various StE productivity and PCR-RFLP types of coa gene, and differences in the frequency of major $\mathrm{StE}$ types (A, B, AC, and ABCD) production between Staph. aureus isolates with the polymorphism of coa gene. The statistical analyses were performed using the Analyze-it program (Analyze-it Software Ltd., Leeds, UK).

\section{RESULTS}

According to phenotypic and biochemical properties, all of the 696 isolates obtained in this study were identified as Staph. aureus. Of these isolates, 164 (23.6\%) were found to be positive for production of one or more toxins using a reverse passive latex agglutination kit (Tables 1 and 2). Of the 164 enterotoxin-producing Staph. aureus isolates, 100 isolates (61.0\%) were involved in production of only one type of StE (SEA, 73 isolates; SEB, 17 isolates; SEC, 8 isolates; SED, 2 isolates). The remaining 64 isolates produced more than one toxin.

The resistance profiles of SES and non-SES isolates to 9 antimicrobial agents were compared. Most isolates were resistant to penicillin and ampicillin, but were susceptible to amikacin, gentamicin, cephalotin, kana- mycin, and tetracyclin (Table 3). Of 696 Staph. aureus isolates obtained from 140 dairy farms between 1997 and 2004, 19 isolates (2.7\%) were methicillin-resistant Staph. aureus (MRSA). Of the 19 MRSA isolates, 13 isolates $(68.4 \%)$ produced one or more StE. Although there are differences in antibiotic resistance patterns shown by different types of SES isolates, the percentage of SES isolates resistant to oxacillin (7.9 vs. 1.1\%), kanamycin ( 43.9 vs. $22.7 \%$ ), neomycin ( 30.5 vs. $12.8 \%$ ), amikacin (26.2 vs. $10.7 \%)$, and tetracycline (32.3 vs. $19.2 \%)$ was greater $(P<0.05)$ compared with non-SES isolates.

For coa genotyping, all 696 isolates were subjected to PCR amplification of the $3^{\prime}$ end of the coa gene and subsequent agarose gel analysis of PCR products, which showed a single band ranging between 620 and 809 bp for each Staph. aureus isolate (Figure 1, panel A). Restriction enzyme digestion (by $A l u \mathrm{I}$ ) of the PCR products generated 10 different coa gene RFLP patterns (I to $\mathrm{X}$ ). The number of fragments produced upon $A l u \mathrm{I}$ digestion varied from 1 to 4 , and their sizes varied from 126 to $670 \mathrm{bp}$ (Figure 1, panel B). These genotypes were observed among Staph. aureus isolates from different geographic locations, but a few genotypes tended to prevail at each location. The main genotypes were I (25.4\%), II (13.9\%), VII (13.2\%), and VIII (17.8\%), and the distribution rates of the 4 main types made up $70.3 \%$ of the isolates (Table 2). Among the 82 dairy farms containing more than 4 isolated Staph. aureus strains per herd in different geographic locations, Staph. aureus strains with only 1 coa gene RFLP pat- 
Table 3. Difference in antibiogram between nonstaphylococcal enterotoxin and staphylococcal enterotoxin (StE)-producing Staphylococcus aureus

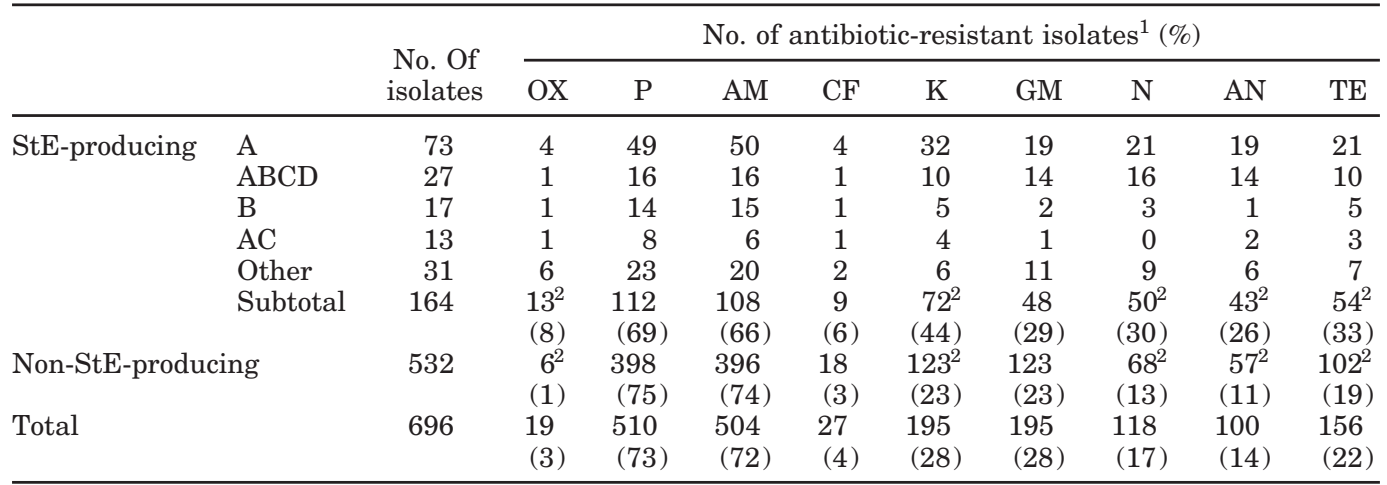

\footnotetext{
${ }^{1} \mathrm{OX}=$ oxacillin, $1 \mu \mathrm{g} ; \mathrm{P}=$ penicillin $\mathrm{G}, 10 \mathrm{U} ; \mathrm{AM}=$ ampicillin, $10 \mu \mathrm{g} ; \mathrm{CF}$ = cephalothin, $30 \mu \mathrm{g} ; \mathrm{K}=$ kanamycin, $30 \mu \mathrm{g} ; \mathrm{GM}$ = gentamicin, $10 \mu \mathrm{g} ; \mathrm{N}$ = neomycin, $30 \mu \mathrm{g} ; \mathrm{AN}=$ amikacin, $30 \mu \mathrm{g}$; $\mathrm{TE}$ = tetracycline, $30 \mu \mathrm{g}$. Methicillin resistance of staphylococci was screened by disk diffusion test with an oxacillin disk on Muller-Hinton agar (Difco, Sparks, MD) and confirmed by MIC test with oxacillin. Phenotypic methicillin resistance was defined with an oxacillin MIC $\geq 4 \mu \mathrm{g} / \mathrm{mL}$.

${ }^{2}$ The percentage of StE-producing Staph. aureus isolates resistant to oxacillin, kanamycin, neomycin, amikacin, and tetracycline was greater $(P<0.05)$ than that of non-StE-producing isolates.
}

tern were isolated from 39 herds $(47.6 \%)$, whereas Staph. aureus strains with 2,3 , or 4 or more coa genotypes were isolated from 23 (28.0\%), 15 (18.3\%), and 5 $(6.1 \%)$ herds, respectively.

When 10 distinct coa genotype patterns were compared between 532 non-SES and 164 SES isolates, the differences in coa genotype carried by specific toxin type was not observed (Table 2). However, the percentage of isolates producing major $\mathrm{StE}$ types $(\mathrm{A}, \mathrm{B}, \mathrm{AC}$, and $\mathrm{ABCD}$ ) was greater among the Staph. aureus isolates with the 4 predominant genotypes (I, II, VII, and VIII) than among the isolates harboring the 6 rare coagulase types (III, IV, V, VI, IX, and X). Additionally, the Staph. aureus isolates carrying predominant coa genotypes were more resistant $(P<0.05)$ to cephalothin compared with the isolates having rare coa types; all the MRSA isolates had the 4 predominant coa genotypes (Table 4).

\section{DISCUSSION}

Milk and other dairy products have been reported to be frequently associated with Staph. aureus enterotoxin food poisoning. It has been supposed that the milk of infected animals may constitute the main source of enterotoxigenic Staph. aureus of animal origin (Bryan, 1983; Bergdoll, 1989; Gilmour and Harvey, 1990). Because of the importance of these toxins for public health and food safety, efficient screening for the prevalence of enterotoxigenic strains in bovine mastitis is necessary. The production of enterotoxins SEA to SEE by Staph. aureus field isolates from mastitis animals has been investigated in several studies (Bautista et al., 1988;
Kenny et al., 1993; Matsunaga et al., 1993; Zschöck et al., 2004).

In this study, the prevalence rate of enterotoxin-producing Staph. aureus from bovine mastitis was $23.6 \%$ when randomly selected field strains were examined. One hundred isolates $(61.0 \%)$ possessed only 1 type of toxin, with SEA (42.9\%) being the most frequent toxin type; the remaining 64 isolates $(39.0 \%)$ participated in production of more than 1 toxin. The predominance of SEA contradicts with reports from countries such as Switzerland, Brazil, and Japan, where SEC-producing Staph. aureus were frequently isolated (Stephan et al., 2001; da Silva et al., 2005; Katsuda et al., 2005). Various reports have indicated that SEA is mainly from humans, whereas SEC is from animals (Bergdoll, 1989; Orden et al., 1992). In contrast, a review by Genigeorgis (1989) concluded that there is no predominant type of $\mathrm{StE}$, apart from the isolates from food involved in staphylococcal gastroenteritis, where SEA is the main type of StE recovered (Genigeorgis, 1989). Further epidemiological study is required to clarify the dominant genotype and toxin type of Staph. aureus in the Republic of Korea by more extensive characterization of a large number of isolates from different geographical areas. As demonstrated in various studies (Su and Wong, 1995; Munson et al., 1998; Zhang et al., 1998), StE-producing strains have been widely isolated from mastitis. Recently, the occurrence of new types of StE has been reported (Zschöck et al., 2005), but none of the newly described enterotoxins (SEG, SEH, SEI, and SEJ) were investigated in this study.

The emergence of antibacterial resistance among pathogens that affect animal health is of growing con- 
A.
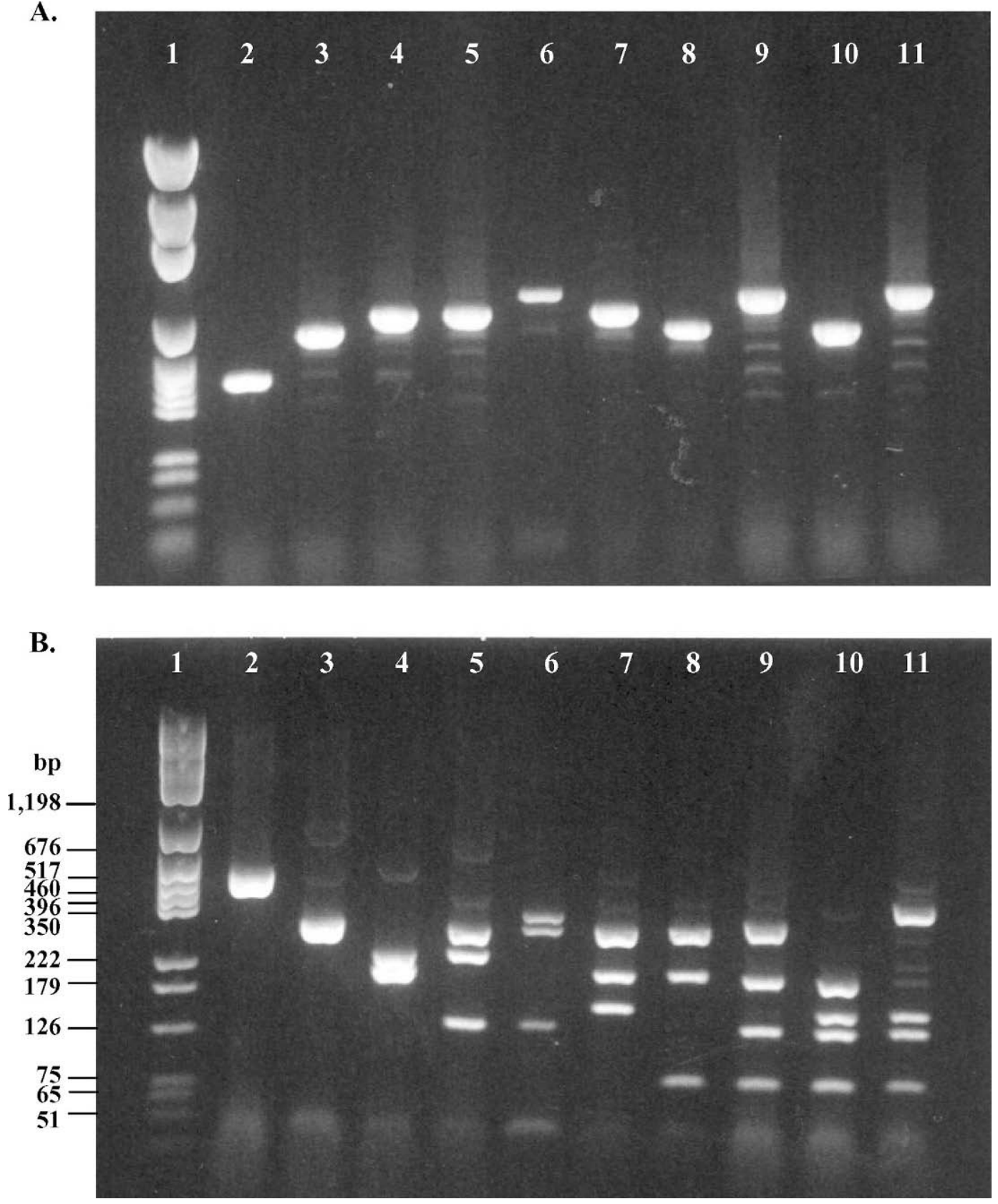

Figure 1. Polymerase chain reaction-RFLP patterns. The coagulase (coa) gene of Staphylococcus aureus was amplified (A) and digested with $A l u$ I restriction endonucleases (Promega Corp, Madison, WI) (B). Lane 1 = 100-bp molecular weight ladder (A) or pGEM DNA marker (B) (Promega); Lanes 2 to 11 = RFLP patterns I to X of the coa gene (B).

cern in veterinary medicine. Antimicrobial-resistant pathogens in animals have been incriminated as a potential health risk for humans from possible transmission as foodborne pathogens. Particularly, mastitis is the single greatest cause of antibacterial use on dairy farms (White and McDermott, 2001; Erskine et al., 2002). Staphylococcus aureus remains one of the most significant organisms associated with bovine mastitis worldwide. It is believed that infections with Staph. aureus respond poorly to therapy with antimicrobial agents, whether given parenterally or via the intramammary route (Vintov et al., 2003). The occurrence and transmission of antimicrobial-resistant Staph. aureus itself or its gene(s) related to antibiotic resistance have been suggested as one of the reasons for the lack of response to therapy (Goh et al., 1992; Kreiswirth 
Table 4. Comparison of antibiograms of Staphylococcus aureus with different coagulase genotypes isolated from bovine mastitis milk

\begin{tabular}{|c|c|c|c|c|c|c|c|c|c|c|c|}
\hline \multirow{2}{*}{$\begin{array}{l}\text { Coagulase genotypes } \\
\text { (I to X) }\end{array}$} & & \multirow{2}{*}{$\begin{array}{l}\text { No. of } \\
\text { isolates }\end{array}$} & \multicolumn{9}{|c|}{ No. of antibiotic-resistant isolates ${ }^{1}(\%)$} \\
\hline & & & OX & $\mathrm{P}$ & $\mathrm{AM}$ & $\mathrm{CF}$ & $\mathrm{K}$ & GM & $\mathrm{N}$ & $\mathrm{AN}$ & $\mathrm{TE}$ \\
\hline \multirow[t]{5}{*}{ Predominant types } & I & 177 & 6 & 144 & 142 & 6 & 48 & 38 & 18 & 22 & 24 \\
\hline & VIII & 124 & 10 & 104 & 103 & 8 & 36 & 34 & 17 & 15 & 46 \\
\hline & II & 97 & 1 & 47 & 47 & 6 & 28 & 41 & 13 & 11 & 23 \\
\hline & VII & 92 & 2 & 63 & 62 & 5 & 22 & 25 & 26 & 23 & 18 \\
\hline & Subtotal & 490 & $\begin{array}{l}19^{2} \\
(4)\end{array}$ & $\begin{array}{c}358 \\
(73)\end{array}$ & $\begin{array}{l}354 \\
(72)\end{array}$ & $\begin{array}{r}25^{2} \\
(5)\end{array}$ & $\begin{array}{c}134 \\
(27)\end{array}$ & $\begin{array}{l}138 \\
(28)\end{array}$ & $\begin{array}{l}74 \\
(15)\end{array}$ & $\begin{array}{c}71 \\
(15)\end{array}$ & $\begin{array}{l}111 \\
(23)\end{array}$ \\
\hline \multirow[t]{7}{*}{ Rare types } & $\mathrm{V}$ & 59 & 0 & 41 & 40 & 0 & 12 & 11 & 10 & 5 & 13 \\
\hline & IV & 51 & 0 & 42 & 43 & 0 & 18 & 17 & 18 & 3 & 9 \\
\hline & IX & 37 & 0 & 34 & 30 & 0 & 4 & 4 & 0 & 1 & 1 \\
\hline & VI & 25 & 0 & 11 & 12 & 1 & 14 & 13 & 12 & 13 & 18 \\
\hline & III & 25 & 0 & 16 & 16 & 0 & 8 & 6 & 4 & 5 & 4 \\
\hline & $\mathrm{X}$ & 9 & 0 & 8 & 9 & 1 & 5 & 4 & 0 & 2 & 0 \\
\hline & Subtotal & 206 & $\begin{array}{r}0^{2} \\
(0)\end{array}$ & $\begin{array}{l}152 \\
(74)\end{array}$ & $\begin{array}{l}150 \\
(73)\end{array}$ & $\begin{array}{r}2^{2} \\
(1)\end{array}$ & $\begin{array}{l}61 \\
(30)\end{array}$ & $\begin{array}{c}55 \\
(27)\end{array}$ & $\begin{array}{c}44 \\
(21)\end{array}$ & $\begin{array}{c}29 \\
(14)\end{array}$ & $\begin{array}{c}45 \\
(22)\end{array}$ \\
\hline Total & & 696 & $\begin{array}{l}19 \\
(3)\end{array}$ & $\begin{array}{l}510 \\
(73)\end{array}$ & $\begin{array}{l}504 \\
(72)\end{array}$ & $\begin{array}{l}27 \\
(4)\end{array}$ & $\begin{array}{l}195 \\
(28)\end{array}$ & $\begin{array}{l}193 \\
(28)\end{array}$ & $\begin{array}{l}118 \\
(17)\end{array}$ & $\begin{array}{l}100 \\
(14)\end{array}$ & $\begin{array}{l}156 \\
(22)\end{array}$ \\
\hline
\end{tabular}

\footnotetext{
${ }^{1} \mathrm{OX}=$ oxacillin, $1 \mu \mathrm{g} ; \mathrm{P}=$ penicillin $\mathrm{G}, 10 \mathrm{U}$; $\mathrm{AM}=$ ampicillin, $10 \mu \mathrm{g}$; $\mathrm{CF}$ = cephalothin, $30 \mu \mathrm{g} ; \mathrm{K}=$ kanamycin, $30 \mu \mathrm{g} ; \mathrm{GM}=$ gentamicin, $10 \mu \mathrm{g} ; \mathrm{N}=$ neomycin, $30 \mu \mathrm{g} ; \mathrm{AN}=$ amikacin, $30 \mu \mathrm{g}$; $\mathrm{TE}$ = tetracycline, $30 \mu \mathrm{g}$. Methicillin resistance of staphylococci was screened by disk diffusion test with an oxacillin disk on Muller-Hinton agar (Difco, Sparks, MD) and confirmed by MIC test with oxacillin. Phenotypic methicillin resistance was defined with an oxacillin MIC $\geq 4 \mu \mathrm{g} / \mathrm{mL}$.

${ }^{2}$ The Staph. aureus isolates harboring the predominant coagulase genotypes (I, VIII, II, and VII) were more resistant $(P<0.05)$ to oxacillin and cephalothin compared with the isolates having rare coagulase types (V, IV, IX, VI, III, and X).
}

et al., 1993). Therefore, establishing an antibiogram of strains is very important from the clinical and economic points of view.

Several studies conducted across the world have reported the susceptibility of Staph. aureus from bovine mastitis to antimicrobial agents. In most of those studies, the frequent occurrence of penicillin resistance has been observed, whereas only a few instances of resistance to other antimicrobial agents have been reported (Stephan et al., 2001; Werckenthin et al., 2001; Erskine et al., 2002; Vintov et al., 2003). The low percentage of Staph. aureus strains resistant to other antimicrobial agents except penicillin and ampicillin was confirmed in this study. Major differences in the occurrence of penicillin resistance have been observed between countries (Aarestrup and Jensen, 1998). Thus, a previous report by Vintov et al. (2003) found high frequencies of penicillin resistance in Ireland $(71.4 \%)$, England (67.3\%), and the United States (50\%), whereas low frequencies were found in Scandinavian countries, including Denmark (18.7\%), Norway (2\%), and Sweden $(28.5 \%)$.

The percentage of penicillin-resistant Staph. aureus isolated in this study was greater compared with studies performed in the United States and other countries (Aarestrup and Jensen, 1998; Erskine et al., 2002; Vintov et al., 2003). This might be related to the routine veterinary use of cloxacillin as dry cow treatment and ampicillin as lactating cow treatment against mastitis in Korea (Moon et al., 2005, 2007). The percentage of SES isolates resistant to oxacillin, kanamycin, neomycin, amikacin, and tetracycline was greater $(P<0.05)$ than that of non-SES isolates. These findings support the suggestion that the SEC of Staph. aureus can escape or efficiently inhibit the immune response during infection and continue to survive in the host. The depressed host immune status may result in persistence of Staph. aureus in the mammary gland, degeneration into chronic mastitis status, and difficulty in treatment because of high antibiotic resistance characteristic of SES (Ferens et al., 1998).

One of the criteria for confirmation of staphylococcal food poisoning is whether the recovered isolates have enterotoxigenicity. In contrast, non-StE-producing Staph. aureus strains are not considered etiologic organisms for food poisoning (Chiou et al., 2000). Additionally, molecular typing of staphylococcal isolates can provide useful information about their epidemiological relatedness for the confirmation of staphylococcal foodborne outbreaks. Numerous methods for Staph. aureus typing have been described (Goh et al., 1992; Chiou et al., 2000). Among these, a subtyping system based on the size and restriction patterns of PCR products of the $3^{\prime}$ end of the coa gene (Goh et al., 1992) was successfully used to examine epidemiological relationships among Australian isolates of bovine Staph. aureus. 
Of the 10 different RFLP patterns observed in this study, the main types were I $(25.4 \%)$, II $(13.9 \%)$, VII (13.2\%), and VIII (17.8\%), and the distribution of the 4 main types accounted for $70.3 \%$ of the isolates. This agrees with results of a study conducted by Aarestrup et al. (1995) in which 187 Staph. aureus bovine isolates were grouped into 15 subtypes based on PCR-RFLP analysis of the coa gene. In contrast, a study conducted by $\mathrm{Su}$ et al. (1999) demonstrated that the profiles of coa genotype determined by PCR-RFLP differed among geographic location from the Czech Republic, France, the Republic of Korea, and the United Kingdom, and only a few genotypes prevailed in each location. These findings supported the conclusions of other studies (Aarestrup et al., 1995; Fitzgerald et al., 1997; Annemüller et al., 1999; Raimundo et al., 1999) in that the limited number of Staph. aureus isolates with dominant coa genotypes occurred in various herds and countries. This difference could reflect the more intensive farming practices used in the Republic of Korea compared with those in Australia, resulting in the smaller number of genotypes in circulating strains.

Sixty-two (75.6\%) Staph. aureus isolates from 82 herds in different locations showed only 1 or 2 coa gene RFLP patterns in this study. Our results support previous findings that only a few coa gene variants predominated, although mastitis in Germany, Switzerland, and Northeast Japan was caused by Staph. aureus strains that had many variants of coa gene (Annemüller et al., 1999; Stephan et al., 2001; Katsuda et al., 2005). Although the difference in genotype by specific toxin type was not shown, the frequency of major StE types $(\mathrm{A}, \mathrm{B}, \mathrm{AC}, \mathrm{ABCD})$ was greater $(P<0.05)$ in the Staph. aureus isolates with the 4 predominant genotypes (I, II, VII, and VIII) compared with the isolates having the 6 rare coagulase types (III, IV, V, VI, IX, and X). This is different from the data published by Katsuda et al. (2005), which indicated that all of 173 isolates with the coa genotype A or B possessed one or more toxin genes, but no toxin gene could be detected in isolates with coa genotype $\mathrm{D}$, except in 3 isolates. This result is in agreement with the findings of previous studies, which showed that a few Staph. aureus clones had broad geographic distribution in different countries (Fitzgerald et al., 1997; Annemüller et al., 1999; Lange et al., 1999).

According to $\mathrm{Su}$ et al. (1999), the predominant coa genotypes were more resistant to neutrophil activities than those with the rare genotype, which indicates that specific features in the former might help them overcome host defense mechanisms. In this study, Staph. aureus isolates harboring the predominant coa genotypes (I, II, VII, and VIII) were more resistant $(P<$ $0.05)$ to oxacillin and cephalothin compared with the isolates having rare coa types (III, IV, V, VI, IX, and
$\mathrm{X})$. Our results demonstrate that the patterns of antimicrobial resistance did not determine the distribution of coa genotypes but may be caused by the diverse selective pressure from the different usage of antibiotics on each farm. Further studies are needed to determine the common characteristics of the predominant strains. In summary, this study indicates that a broad distribution of identical or closely related enterotoxin-producing or methicillin-resistant Staph. aureus strains contributes to the bovine mastitis problem in the Republic of Korea.

\section{ACKNOWLEDGMENTS}

This work was supported by a grant from the National Veterinary Research and Quarantine Services, Republic of Korea. H. C. Koo and Y. H. Park were supported by the Korean Research Foundation Grant (KRF-2006-005-J02903), Research Institute of Veterinary Science, Department of Veterinary Microbiology, College of Veterinary Medicine, and BK21 Program for Veterinary Science, Seoul National University.

\section{REFERENCES}

Aarestrup, F. M., C. A. Dangler, and L. M. Sordillo. 1995. Prevalence of coagulase gene polymorphism in Staphylococcus aureus isolates causing bovine mastitis. Can. J. Vet. Res. 59:124-128.

Aarestrup, F. M., and N. E. Jensen. 1998. Development of penicillin resistance among Staphylococcus aureus isolated from bovine mastitis in Denmark and other countries. Microb. Drug Resist. $4: 247-256$.

Annemüller, C., C. H. Lammler, and M. Zschöck. 1999. Genotyping Staphylococcus aureus isolated from bovine mastitis. Vet. Microbiol. 69:217-224.

Bautista, L., P. Gaya, M. Medina, and M. Nunez. 1988. A quantitative study of enterotoxin production by sheep milk staphylococci. Appl. Environ. Microbiol. 54:566-569.

Bergdoll, M. S. 1989. Staphylococcus aureus. Pages 463-523 in Foodborne Bacterial Pathogens. M. P. Doyle, ed. Marcel Dekker Inc., New York, NY.

Boerema, J. A., R. Clemens, and G. Brightwell. 2006. Evaluation of molecular methods to determine enterotoxigenic status and molecular genotype of bovine, ovine, human and food isolates of Staphylococcus aureus. Int. J. Food Microbiol. 107:192-201.

Bramley, A. J. 1992. Mastitis. Pages 289-300 in Bovine Medicine: Diseases and Husbandry of Cattle. A. H. Andrews, R. W. Blowey, H. Boyd, and R. G. Eddy, ed. Blackwell Scientific, Boston, MA.

Bryan, F. L. 1983. Epidemiology of milk-borne diseases. J. Food Prot. 46:637-649.

Chiou, C. S., H. L. Wei, and L. C. Yang. 2000. Comparison of pulsefield gel electrophoresis and coagulase gene restriction profile analysis techniques in the molecular typing of Staphylococcus aureus. J. Clin. Microbiol. 38:2186-2190.

Clinical and Laboratory Standards Institute (CLSI). 2002. Performance Standards for antimicrobial disk susceptibility tests for bacteria isolated from animals. Approved Standard M32-A2. 2nd ed. CLSI, Wayne, PA.

Cremonesi, P., L. Massimo, M. Brasca, S. Morandl, R. Lodi, C. Vimercati, D. Agnellini, G. Caramenti, P. Moroni, and B. Castiglioni. 2005. Development of a multiplex PCR assay for the identification of Staphylococcus aureus enterotoxigenic strains isolated from milk and dairy products. Mol. Cell. Probes 19:299-305.

da Silva, E. R., and N. da Silva. 2006. Coagulase gene typing of Staphylococcus aureus isolated from cow with mastitis in southeastern Brazil. Can. J. Vet. Res. 69:260-264. 
da Silva, E. R., L. S. do Carmo, and N. da Silva. 2005. Detection of the enterotoxin A, B, and C genes in Staphylococcus aureus from goat and bovine mastitis in Brazilian dairy herds. Vet. Microbiol. 106:103-107.

Erskine, R. J., R. D. Walker, C. A. Bolin, P. C. Bartlett, and D. G. White. 2002. Trends in antibacterial susceptibility of mastitis pathogens during a seven-year period. J. Dairy Sci. 85:1111-1118.

Ferens, W. A., W. C. Davis, M. J. Hamilton, Y. H. Park, C. F. Deobald, L. Fox, and G. Bohach. 1998. Activation of bovine lymphocyte subpopulations by staphylococcal enterotoxin C. Infect. Immun. 66:573-580

Fitzgerald, J. R., W. J. Meaney, P. J. Hartigan, and C. J. Smyth. 1997. Fine-structure molecular epidemiological analysis of Staphylococcus aureus recovered from cows. Epidemiol. Infect. 119:261-269.

Gilmour, A., and J. Harvey. 1990. Staphylococci in milk and milk products. Soc. Appl. Bacteriol. Symp. Ser. 19:147S-166S.

Genigeorgis, C. A. 1989. Present state of knowledge on staphylococcal intoxication. Int. J. Food Microbiol. 9:327-360.

Goh, S. H., S. K. Byrne, J. L. Zhang, and A. W. Chow. 1992. Molecular typing of Staphylococcus aureus on the basis of coagulase gene polymorphism. J. Cli. Microbiol. 30:1642-1645.

Harmon, R. J., R. J. Eberhart, D. E. Jasper, B. E. Langlois, and R. A. Wilson. 1990. Microbiological procedures for diagnosis of bovine udder infection. National Mastitis Council, Arlington, VA.

Hookey, J. V., J. F. Richardson, and B. D. Cookson. 1998. Molecular typing of Staphylococcus aureus based on PCR restriction fragment length polymorphism and DNA sequence analysis of coagulase gene. J. Clin. Microbiol. 36:1083-1089.

Kaida, S., T. Miyata, Y. Yoshizawa, H. Igarashi, and S. Iwanaga. 1989. Nucleotide and deduced amino acid sequence of coagulase gene from Staphylococcus aureus strain 213. Nucleic Acids Res. 17:8871.

Katsuda, K., E. Hata, H. Kobayashi, M. Kohmoto, K. Kawashima, H. Tsunemitsu, and M. Eguchi. 2005. Molecular typing of Staphylococcus aureus isolated from bovine mastitic milk on the basis of toxin genes and coagulase gene polymorphism. Vet. Microbiol. 105:301-305.

Kenny, K., R. F. Reiser, F. D. Bastida-Corcucra, and N. L. Norcross. 1993. Production of enterotoxins and toxic shock syndrome toxin by bovine mammary isolates of Staphylococcus aureus. J. Clin. Microbiol. 31:706-707.

Kreiswirth, B., J. Kornblum, and R. D. Arbeit. 1993. Evidence for a clonal origin of methicillin resistance in Staphylococcus aureus. Science 259:227-230.

Lange, C., M. Cardoso, D. Senczek, and S. Schwarz. 1999. Molecular subtyping of Staphylococcus aureus isolates from cases of bovine mastitis in Brazil. Vet. Microbiol. 67:127-141.

Larsen, H. D., A. Huda, N. H. Eriksen, and N. E. Jensen. 2000. Differences between Danish bovine and human Staphylococcus aureus isolates in possession of superantigens. Vet. Microbiol. 76:153-162.

Lim, S. K., Y. S. Joo, J. S. Moon, A. R. Lee, H. M. Nam, S. H. Wee, and H. B. Koh. 2004. Molecular typing of enterotoxigenic Staphylococcus aureus isolated from bovine mastitis in Korea. J. Vet. Med. Sci. 66:581-584.

Llewelyn, M., and J. Cohen. 2002. Superantigens: Microbial agents that corrupt immunity. Lancet Infect. Dis. 2:156-162.

Matsunaga, T., S. Kamata, N. Kakiichi, and A. Uccida. 1993. Characteristics of Staphylococcus aureus isolated from peracute, acute and chronic bovine mastitis. J. Vet. Med. Sci. 55:297-300.

Moon, J. S., H. M. Kang, E. S. Lee, A. R. Lee, and M. N. Kim. 2005. Antibiotic resistance and $\beta$-lactamase production of Staphylococcus aureus isolated from bovine mastitis. Korean J. Vet. Public Health 29:121-129.

Moon, J. S., A. R. Lee, H. M. Kang, E. S. Lee, M. N. Kim, Y. H. Paik, Y. H. Park, Y. S. Joo, and H. C. Koo. 2007. Phenotypic and genetic antibiogram of methicillin-resistant staphylococci isolated from bovine mastitis in Korea. J. Dairy Sci. 90:1176-1185.

Moon, J. S., A. R. Lee, S. K. Lym, Y. S. Joo, H. M. Kang, J. M. Kim, and M. N. Kim. 2003. Epidemiological investigation of Staphylococcus aureus isolated from bovine mastitis based on the polymorphism of coagulase gene. Korean J. Vet. Res. 43:95-102.

Munson, S. H., M. T. Tremaine, M. J. Betley, and R. A. Welch. 1998. Identification and characterization of staphylococcal enterotoxin types G and I from Staphylococcus aureus. Infect. Immun. 66:3337-3348.

Orden, J. A., J. Goyache, J. Hernández, A. Doménech, G. Suárez, and E. Gómez-Lucia. 1992. Detection of enterotoxins and TSST1 secreted by Staphylococcus aureus isolated from ruminant mastitis. Comparison of ELISA and immunoblot. J. Appl. Bacteriol. 72:486-489.

Raimundo, O., M. Deighton, J. Capstick, and N. Gerraty. 1999. Molecular typing of Staphylococcus aureus of bovine origin by polymorphisms of the coagulase gene. Vet. Microbiol. 66:275-284.

Roberson, J. R., L. K. Fox, and D. D. Hancock. 1992. Evaluation methods for differentiation of coagulase positive staphylococci. J. Clin. Microbiol. 30:3217-3219.

Scherrer, D., S. Corti, J. E. Muehlherr, C. Zweifel, and R. Stephan. 2004. Phenotypic and genotypic characteristics of Staphylococcus aureus isolates from raw bulk-tank milk samples of goats and sheep. Vet. Microbiol. 101:101-107.

Schwarzkopf, A., and H. Karch. 1994. Genetic variation in Staphylococcus aureus coagulase genes: Potential and limits for use as epidemiological marker. J. Clin. Microbiol. 32:2407-2412.

Stephan, R., C. Annemüller, A. A. Hassan, and C. H. Lämmler. 2001. Characterization of enterotoxigenic Staphylococcus aureus strains isolated from bovine mastitis in north-east Switzerland. Vet. Microbiol. 79:373-382.

Su, C., C. Herbelin, N. Frieze, O. Skardova, and L. M. Sordillo. 1999. Coagulase gene polymorphism of Staphylococcus aureus isolates from dairy cattle in different geographical areas. Epidemiol. Infect. 122:329-336.

Su, Y. C., and A. C. Wong. 1995. Identification and purification of a new staphylococcal enterotoxin H. Appl. Environ. Microbiol. 61:1438-1443.

Tsen, H. Y., and T. R. Chen. 1992. Use of the polymerase chain reaction for specific detection of type A, D and $\mathrm{E}$ enterotoxigenic Staphylococcus aureus in foods. Appl. Microbiol. Biotechnol. 37:685-690.

Vintov, J. A. N., F. M. Aarestrup, C. E. Zinn, and J. E. Olsen. 2003. Association between phage types and antimicrobial resistance among bovine Staphylococcus aureus from 10 countries. Vet. Microbiol. 95:133-147.

Watts, J. L. 1988. Etiological agents of bovine mastitis. Vet. Microbiol. 16:41-66.

Werckenthin, C., M. Cardoso, J. L. Martel, and S. Schwarz. 2001. Antimicrobial resistance in staphylococci from animals with particular reference to bovine Staphylococcus aureus, porcine Staphylococcus hyicus, and canine Staphylococcus intermedius. Vet. Res. 32:341-362.

White D. G., and P. F. McDermott. 2001. Emergence and transfer of antibacterial resistance. J. Dairy Sci. 84(E. Suppl.):E151-E155.

Zhang, S., J. J. Iandolo, and G. C. Stewart. 1998. The enterotoxin D plasmid of Staphylococcus aureus encodes a second enterotoxin determinant (sej). FEMS Microbiol. Lett. 168:227-233.

Zschöck, M., B. Kloppert, W. Wolter, H. P. Hamann, and Ch. Lämmler. 2005. Pattern of enterotoxin genes seg, seh, sei and sej positive Staphylococcus aureus isolated from bovine mastitis. Vet. Microbiol. 108:243-249.

Zschöck, M., K. Risse, and J. Sommerhauser. 2004. Occurrence and clonal relatedness of sec/tst-gene positive Staphylococcus aureus isolates of quarter milk samples of cows suffering from mastitis. Appl. Microbiol. Lett. 38:493-498. 